\author{
Седікова І.О. \\ доктор економічних наук, доцент \\ кафедра менеджменту та логістики \\ Одеська національна академія харчових технологій \\ вул. Канатна, 112, м. Одеса, Україна, 65039 \\ E-mail: kaf.ml332@gmail.com
}

\title{
УПРАВЛІННЯ ПРОФЕСІЙНО-КВАЛІФІКАЦІЙНИМ РОЗВИТКОМ ПРАЦІВНИКІВ НА ПІДПРИЕМСТВАХ ВИНОРОБНОЇ ГАЛУЗІ
}

Проведене дослідження присвячено удосконаленню системи управління професійнокваліфрікаційним розвитком працівників виноробних підприємств Розкрито основні етапи управління кваліфікаційним розвитком працівників, визначено шляхи підвищення кваліфікації. Узагальнено інфоормацію щодо основних показників з питань оцінки кадрового потенціалу на підприємствах виноробної галузі задля оцінки ролі та якості кадрового потенціалу підприємств виноробної галузі.

Ключові слова: управління, професійно-кваліфікаційний розвиток, виноробна галузь, персонал.

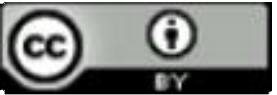

This work is licensed under a Creative Commons Attribution 4.0 International License http://creativecommons.org/licenses/by/4.0/
Постановка проблеми та її зв'язок з важливими науковими та практичними завданнями. В умовах сьогодення постійно зростає інтерес до проблем становлення, розвитку та вдосконалення рівня професійних компетенцій фахівців підприємств виноробної галузі. Від рівня їх професійної кваліфікації залежить ефективність праці колективу та всього підприємства. У соціально орієнтованих економічних системах особливе місце в становленні, функціонуванні та розвитку належить її суб' єктам як активній рушійній, перетворюючій силі. Кожний суб'єкт є носієм певних прав, обов'язків та відповідальності, які реалізує в процесі своєї діяльності. Сьогодні питання підвищення рівня професійної діяльності є дуже актуальним на різних етапах функціонування підприємств виноробної галузі, що відповідає вимогам часу. Реалізацію відповідної підготовки можна завдяки досвіду або 3 використанням спеціальних інноваційних освітніх технологій.

Аналіз останніх публікацій по проблемі. Проблеми ефективного управління підприємствами відображено в наукових працях: М. Височина, В. Гриньова, Ю. Дмитрієва, П. Друкер, Ю. Запознова, С. Єлецьких, М. Іванова, А. Кібанов, В. Коломієць. Вивченню особливостей управління професійнокваліфікаційним розвитком працівників на підприємствах виноробної галузі присвячена значна кількість досліджень: О. Амоші, Л. Антонюк, Л. Балобанова, М. Войнаренко, В. Зянько, С. Ілляшенка, Є. Коржова та ін. [1, 2, 3, 4, 5]. Високо оцінюючи публікації названих авторів, доцільно вказати на необхідність продовження здійснених розробок у напрямах управління професійно-кваліфікаційним розвитком працівників на підприємствах виноробної галузі, оцінки ефек- тивності їх діяльності. Необхідність дослідження цих проблем, їх актуальність і практична значущість визначили вибір теми дослідження.

Формулювання цілей дослідження. Мета статті полягає у досліджені напрямів удосконалення системи управління професійно-кваліфікаційним розвитком працівників виноробних підприємств.

Виклад основних результатів та їх обгрунтування. Підвалину будь-якого фахівця складає його особистість, яка надає здобуттю професійної освіти, професійному становленню та розвитку яскраво особистісного смислу, унікальної індивідуальної траєкторії, неповторного характеру, інколи навіть неочікуваного результату. Адаменко Є. стверджує, що «... професійний розвиток працівника - це набуття працівником нових знань і навичок, які він зможе використовувати у своїй професійній діяльності» [6, с. 236]. Автори дослідження [7, с. 61] визначають, що «...професійний розвиток працівника - це процес підготовки працівника підприємства до виконання та вирішення ним нових трудових завдань». Автори дослідження [10, с. 28] стверджують, що «професійний розвиток - це рівнонаправлений, нерівноважний i відкритий процес зміни особи в результаті освоєння і виконання професійно-освітньої і професійної діяльності». Отже, можна стверджувати, що підвищення рівня професійних компетенцій персоналу підприємства вимагає нових умов оцінки персоналу - визначення рівня професійних, ділових знань та вмінь працівника [8]. Завданнями професійного розвитку персоналу підприємства $\epsilon$ «підвищення кваліфікації 3 метою випуску нової продукції, правильного використання, техобслуговування та ремонту засобів виробництва, підготовка та перепідготовка кадрів, навчан- 
ня сучасним технологіям; здатність до комунікації, роботі в групі....» [9, с. 36-45].

Для чого людина працює? Якщо відповідь буде «для роботи» або «так положено», то можна казати, ця людина не налаштована на кар'єрний ріст та досягнення високих результатів своєї професійної діяльності. Вони завжди прагнуть працювати під керівництвом інших та виконувати лише поставлені завдання, не прагнуть стати керівником. Але якщо людина відповідає на це питання: «Для заробітку грошей» або «Для реалізації своїх можливостей», то це амбіційна, цілеспрямована і працелюбна людина, яка готова працювати, навчатися і розвиватися для забезпечення кар'єрного росту на підприємстві компанії та підвищення свого фінансового стану. 3 перших днів роботи такі співробітники уважно вивчають всі можливості кар'єрного просування на підприємстві. Це досить просто, якщо підприємство невелике і має не більше 50 співробітників. На підприємствах 3 кількістю співробітників понад 200 чоловік для нового співробітника важко визначити, яким чином він зможе забезпечити собі можливість кар'єрного росту на підприємстві. I основна складність складається в заплутаній організаційній структурі компанії, безлічі департаментів, керівників, їх заступників та відповідальних осіб. Така складна організація призводить до того, що талановиті, цілеспрямовані співробітники втрачаються, їм важко розібратися в послідовності дій для професійного розвитку та кар'єрного росту на підприємстві. Для кожної компанії дуже важливо, щоб співробітники розвивалися не «з-під палки», а самостійно прагнули стати висококваліфікованими професіоналами.

Існує декілька способів пояснити працівникам підприємства можливості кар'єрного росту в організації. Одним 3 найбільш ефективних способів на сьогоднішній день $є$ «кар'єрний компас» - схематичний рисунок, на якому відображені всі етапи кар'єрного росту та професійного розвитку співробітників. «Кар'єрний компас» показує кожному співробітнику його шлях та етапи кар'єрного росту в організації.

Економічна криза та постійні зміни, які відбуваються у мінливому середовищі функціонування підприємств виноробної галузі вказують на необхідність всебічного вивчення та пошуку шляхів вирішення проблем, що стримують розвиток суб'єктів господарювання. Узагальнення проведених досліджень та власні спостереження автора дають змогу стверджувати, що пріоритетним напрямом забезпечення якості системи управління кадровим розвитком $\epsilon$ удосконалення взаємодії керуючої та керованої систем в рамках обраної стратегії розвитку. За таких умов виникає необхідність у визначенні основних засад кадрового забезпечення якості системи управління кадровим розвитком.

Виробництво вина - $є$ одним із основних бюджетоутворюючих агропромислових сфер України, що істотно впливає на соціально-економічний розвиток регіонів. За даними статистики, у 2016 році в Україні вирощуванням винограду займались 494 під- приємства, в Одеській області - 209. Обсяг виробництва виноградних вин в Одеській області складає 43,9 \%. У даному дослідженні для оцінки професійних якостей кадрового потенціалу узагальнено дані щодо показників оцінки кадрового потенціалу на підприємствах виноробної галузі.

Проведений аналіз за групою «Підготовка кадрів» свідчить, що на підприємствах виноробної галузі помітно збільшується група працівників, які впроваджують інноваційні технології виробництва, застосовують інноваційні технології управління - на 9,6 \%. Щодо складу працівників з вищою освітою, які задіяні у виробництві, то їх частка складає - $44 \%$. Слід зауважити, що у виноробній промисловості не має такої групи працівників, як раціоналізатори і винахідники. Перепідготовка та навчання кадрів відбувається безпосередньо на підприємствах. Встановлено, що у 2015 р. таку форму підготовки кадрів використовували для 59 \% працівників, які навчалися новим професіям. Підприємства заключають договори 3 BН3 I-IV рівнів акредитації на навчання працівників. Дані свідчать про те, що підготовка кадрів у навчальних закладах різних типів за договорами у 2016 році склала $16,5 \%$, зокрема у ВН3 I-IV рівнів акредитації - 35,4\%. Так, 14 - 22 \% працівників, що навчаються, обрали вищу освіту та їх частка постійно зростає, наприклад, у 2016 р. порівняно з 2014 р. відбулось збільшення майже у 1,7 рази. Проведений аналіз встановив, що на підприємствах, які досліджувались не впроваджують такі форми підвищення кадрового потенціалу (для працівників вищого рівня управління), як навчання новим професіям та стажування за кордоном, що $є$ актуальним в умовах виходу вітчизняного ринку із кризи.

Проблемним для виноробних підприємств залишається питання забезпечення спеціалістамивиноробами. Вітчизняні ВНЗ щорічно випускають близько 150 молодих спеціалістів-виноробів, 3 яких лише 2-5 \% можуть працевлаштуватись на підприємствах. Монополізований ринок виробництва (256 підприємства в Україні, 87 підприємств в Одеській області, до прикладу, 6,5 тис. виноробних підприємств у Австрії) та низька привабливість науково-дослідної роботи формують вкрай загрозливу тенденцію кадрового забезпечення розвитку галузі [11].

Для оцінки ефективності управління професійно-кваліфікаційним розвитком працівників використовують різноманітні методики, які можна виокремити у дві групи: вартісні і не вартісні. В рамках першої групи виділяють вартісний та доходний підходи. Вартісний підхід відображає витрати на створення потенціалу (фонд заробітної плати, фонд матеріального заохочення i витрат на перепідготовку i підвищення кваліфікації кадрів). Доходний підхід передбачає капіталізацію частини прибутку підприємства, отриману за рахунок його кадрового потенціалу. Не вартісні методики базуються на оцінці кадрового потенціалу як чисельності працівників, фонду часу працівників, обсягу виробленої продукції, а також у бальному або коефіцієнтному вигляді. Для визначення узагальнюючого показника кадрового 
потенціалу рекомендується методика, яка базується на еталонній оцінці, тобто порівнянні фактичних характеристик працівників 3 їх еталонними значеннями у балах.

Етапи реалізації методики.

1. Оцінка ступеню важливості окремих характеристик робітників за допомогою рангів (експертним шляхом) і перевірка значущості результатів експертних оцінок за допомогою коефіцієнтів конкордації.

2. Перетворення отриманих рангів на питомі ваги значущості.

3. Розроблення форм анкет для кожної категорії і анкетування мінімум 20 \% робітників 4-х категорій.

4. Обробка i усереднення результатів всередині кожної категорії працівників.

5. Розрахунки рівня кадрового потенціалу по категоріях персоналу i узагальнюючого показника кадрового потенціалу підприємства. Для визначення індивідуального кадрового потенціалу кожного із працівників, виокремлюємо їх у дві групи, об'єднаних спорідненими функціями діяльності: перша група - робітники, друга - службовці, спеціалісти і керівники.
Для оцінки ефективності показників з професійного навчання персоналу існують різні методичні підходи, розглянемо один з них. Збільшення обсягів прибутку підприємства за рахунок підвищення кваліфікації внаслідок підвищення продуктивності праці персоналу оцінюється за формулою:

$$
E_{e n 2}=\sum_{i=1}^{n} \frac{\left(\Pi_{H \Pi 2 i}-\Pi_{H \Pi 1 i}\right) * Y_{\Pi i}-P_{H i}}{100}
$$

де Ееn2 - річний економічний ефект від збільшення обсягу прибутку фірми у результаті професійного навчання персоналу, грн.;

Пнn 1, Пнn $2 i$ - середня продуктивність праці персоналу і-тої професії, які відповідно не пройшли i пройшли навчання за програмою підготовки, грн.;

Чni - чисельність працівників і-тої професій, які пройшли професійне навчання за направленням фірми, осіб;

Рнi - рівень прибутку у розрахунку на 1 грн. виготовленої продукції (наданих послуг) працівниками і-тої професії, \%.

Результати розрахунку економічної ефективності підвищення кваліфікації працівників підприємств виноробної галузі наведено у табл. 1.

Таблиця 1

Розрахунок економічної ефективності підвищення кваліфікації працівників*

\begin{tabular}{|l|r|}
\hline $\begin{array}{l}\text { Середня продуктивність праці працівників і-тої професії, які не пройшли підвищення кваліфі- } \\
\text { кації за програмою навчання, тис. грн. }\end{array}$ & 100 \\
\hline $\begin{array}{l}\text { Середня продуктивність праці працівників і-тої професії, які пройшли підвищення кваліфіка- } \\
\text { ції за програмою навчання, тис. грн. }\end{array}$ & 120 \\
\hline $\begin{array}{l}\text { Численність персоналу і-тої професії, які пройшли підвищення кваліфікації за програмою на- } \\
\text { вчання, осіб. }\end{array}$ & 30 \\
\hline Рівень прибутку у розрахунку на 1 грн. виготовленої продукції працівниками і-тої професії, \% & 15 \\
\hline
\end{tabular}

* авторська розробка

Ефективність від професійного навчання працівників визначають шляхом зіставлення отриманого приросту ВВП та/або частки виноробної галузі, суспільної продуктивності праці з витратами, понесеними на навчання. Основу даного методу складають опосередковані методи визначення ефективності професійного навчання шляхом використання порівняльного аналізу показників економічного росту та показників розвитку вищої та професійно-технічної освіти, підготовки персоналу на підприємствах, в динаміці. Рівні зайнятості та безробіття населення свідчать про ефективність професійної освіти на макроріBнi.

Висновки та перспективи подальших досліджень. У даному досліджені проведено аналіз напрямів підвищення кадрового потенціалу на підприємствах виноробної галузі, шляхом удосконалення системи управління професійно-кваліфікаційним розвитком працівників. За результатом дослідження сформульовані висновки:

1. Система управління кадровим потенціалом повинна відповідати сучасним вимогам турбулентного зовнішнього середовища. Головним призначенням даної системи є узгодження заходів щодо стабільного функціонування системи управління професійнокваліфікаційним розвитком працівників.

2. Для досягнення означеної мети автором означені основні чинники, які сприяють створенню сучасного кадрового потенціалу, а саме: формування ефективної системи підготовки менеджерів нової формації та новим світоглядом; забезпеченість виробництва висококваліфікованими спеціалістами (технологами, виноробами, менеджерами, логістами); формування у спеціалістів світогляду працювати за принципом «орієнтації на кінцевий результат»; головним в системі управлінських функцій має стати відповідальність за виконану роботу; володіння інноваційними управлінськими механізмами; поступальна орієнтація управлінської діяльності на якісне виконання всіх бізнес-процесів; відбір менеджерів для роботи на керівних посадах, у тому числі на таких, що вимагають постійних змін методів та механізмів управління.

3. Розробка комплексної моделі системи кадрового забезпечення виноробних підприємств, яка може адаптуватися до змін мисливого середовища та в основу якої покладена спільна діяльності ВНЗ, науково-дослідних установ. 
4. Реалізація програми довгострокової профорієнтаційної підготовки фахівців повинна відбуватися за наскрізними навчальними планами та програмами. В іiї основу повинно бути покладено ефективне використання навчально-лабораторної, наукової та виробничої бази, щодо організації підвищення кадрового потенціалу підприємств, спільному проведенні науково-дослідних робіт, апробації та використанні результатів наукових досліджень.
Усвідомлення всебічного стратегічного бачення проблем розвитку кадрового потенціалу підприємств виноробної галузі як механізму, який оперує не тільки технічним та програмним забезпеченням, але й інноваційними методами ефективного управління, дасть змогу перейти на новий якісний рівень підвищення кадрового потенціалу підприємств галузі, що своїм чином призведе до стабілізації та підвищення конкурентоспроможності як на внутрішньому та i на зовнішньому ринку.

\title{
Література
}

1. Грэхем Х. Т. Управление человеческими ресурсами: [учеб. пособ. для вузов] / Х. Т. Грэхем, Р.Беннетт; пер. с англ. под ред. Т. Ю. Базарова и Б. Л. Еремина. - М.: ЮНИТИ-ДАНА, 2003. - 598 с.

2. Кибанов А. Я. Основы управления персоналом: [учеб.] - М.: ИНФРА - М, 2002. - 735 с.

3. Савченко В.А. Управління розвитком персоналу: [навч. посіб.] / В.А. Савченко. - К.: КНЕУ, 2002. 284 c.

4. Маслов Е. Управление персоналом предприятия: [учеб. пособ.] / Е.Маслов ; под ред. П. Шеметова. М.: ИНФРА-М, Новосибирск, 2000. - 315 с.

5. Шекшня С. Управление персоналом современной организации: [учеб.- практ. пособие.] / С. Шекшня. - М.: Бизнес-школа - Интел-Синтез, 2014. - 478 с.

6. Адаменко Е. Профессиональное обучение персонала / Е. Адаменко // Менеджер по персоналу. 2015. - № 11. - С. 58-62.

7. Мировой винный рынок: перераспределение сил [Електроний ресурс]. - Режим доступу: https://ubr.ua/market/agricultural-market/vinnyi-rynok-otrezvliaushie-tendencii-261254

8. Поваляева М. Н. Порядок обучения рабочего персонала / М. Н. Поваляева // Управление развитием персонала. - 2013. - № 01 (09). - С. 36-45.

9. Карловец С. С. Проблема развития персонала: современный взгляд / С. С. Карловец // Управление развитием персонала. - 2011. - № 01 (25). - С. 26-31.

10. Доклад о развитии человека за 2015 год. Нью-Йорк, по заказу ПРООН. - 262 с.

11. Стан виноробної галузі у світі [Електронний ресурс]. - Режим доступу: http://take-profit.org/ economicnews.php.

Стаття надійшла 08.10.2017

Стаття прийнята до друку 22.10.2017

Доступно в мережі Internet 30.12.2017

\author{
Седикова И.А. \\ доктор экономических наук, доцент \\ кафедра менеджмента и логистики \\ Одесская национальная академия пищевых технологий \\ ул. Канатная, 112, г. Одесса, Украина, 65039 \\ E-mail: kaf.ml332@gmail.com
}

\section{УПРАВЛЕНИЕ ПРОФЕССИОНАЛЬНО-КВАЛИФИКАЦИОННЫМ РАЗВИТИЕМ РАБОТНИКОВ НА ПРЕДПРИЯТИЯХ ВИНОДЕЛЬЧЕСКОЙ ОТРАСЛИ}

\footnotetext{
Целью статьи является теоретическое обоснование и разработка практических рекомендаций по совершенствованию управления профессионально-квалификационным ростом работников винодельческих предприятий. В статье раскрыты основные принципы управления профессиональноквалификационным ростом работников на предприятиях винодельческой отрасли. Определены потребности в подготовке, переподготовке и повышении квалификации работников. В исследовании для определения роли и качества кадрового потенциала предприятий винодельческой отрасли региона обобщена информация по основным показателям оценки кадрового потенциала на предприятиях винодельческой отрасли.
} 
Установлено, что развитие работника - это приобретение работником новых знаний и навыков, которые он сможет использовать в своей профессиональной деятельности. Доказано, что мотивами стимулирования профессионального развития могут быть: сохранение должности или получения другой, обеспечение стабильности или увеличения доходов, расширения контактов работника, приобретение новых знаний, позволяет повысить его конкурентоспособность на рынке труда. Рассмотрены подходы к определению показателей экономической эффективности мероприятий по профессиональному обучению персонала. По результатам исследования сформулированы следующие выводы: Система управления кадровым обеспечением, адекватная современным требованиям и потребностям, должна обеспечивать переход от нескоординированных и не согласованных мер к системному формированию высокопрофессионального, гибкого, новаторского кадрово-управленческого потенциала, способного удовлетворять требованиям современного этапа, на основе новейших достижений отечественной и мировой науки и практики. Доказано, что важнейшими факторами достижения цели создания современного кадрового потенциала является эффективное функционирование системы подготовки специалистов по управлению; умение работать по принципу ориентации на конечный результат; владение новейшими управленческими технологиями; поступательная ориентация управленческой деятельности на совершенное управление. Осознание необходимости стратегического видения проблем кадровой политики предприятий винодельческой отрасли как инструментария эффективного управления, позволит повысить кадровый потенциал предприятий отрасли и приведет к стабилизации и экономической эффективности их деятельности.

Ключевые слова: управление, профессионально-квалификационное развитие, винодельческая отрасль, персонал.

\section{Sedikova I.}

Doctor of Economics, Associate Professor Department of Management and Logistics

Odessa National Academy of Food Technologies

Kanatna str., 112, Odesa, Ukraine, 65039

E-mail: kaf.ml332@gmail.com

\section{MANAGEMENT OF PROFESSIONAL-QUALIFICATION DEVELOPMENT OF EMPLOYEES IN WINERY INDUSTRIES}

The purpose of the article is the theoretical synthesis and development of practical recommendations for improving the management of professional and qualification growth of wine-making enterprises employees. The theoretical generalization and development of practical recommendations for improving the management of professional development of workers of winemaking enterprises were made in the research. The article describes the basic principles of management of professional qualification development of workers at the enterprises of the wine-making industry. The needs for training, retraining and skills development of the wine industry employees have been identified. In the research, for determination of the role and quality of the personnel potential of enterprises in the wine-growing field of the region, the information of main indicators the human resource potential assessment at the enterprises of the winemaking industry was summarized.

It has been established that the development of an employee is her acquisition of new knowledge and skills that he can use in his professional activities. It has been proved that the motives for stimulating professional development can be: maintaining of a position or obtaining another, one ensuring of stability or increasing revenues, expanding an employee's contacts, gaining new knowledge, which will allow to increase its competitiveness in the labour market. The methodical approaches to determination of indicators of economic efficiency of measures on professional training of the personnel have been considered. According to the results of the research, the following conclusions have been formulated: The personnel management system, which is adequate to the modern requirements and needs, should ensure the transition from inadequately coordinated and not always coordinated measures to resolving issues accorsing to the systematic formation of highly professional, flexible, innovative staff potential capable of meeting the requirements of modern and subsequent periods based on the basis of the latest achievements of domestic and world science and practice. It has been proved that the most important factors in achieving the goal of creating a modern staffing potential are: effective functioning of the system of training specialists in management; full (by number and professional criteria) security provided by management specialists; the ability of management specialists to work by the principle of targeting the end result; withdrawal of managerial functions at the forefront of responsibility in the system; their possession of the latest 
management technologies; the progressive orientation of management activity to the perfect management; selection of managers and functional specialists for their use in the most important areas of production, including those requiring modernization and changes in the enterprise or management structure. Awareness of the need for a strategic vision of the problems of the personnel policy of efficient management wines (winemaking) enterprises as an instrument of equipped not only with technique and software, but also modern methods of effective management, will significantly increase the personnel potential of enterprises and industry, which under certain conditions, will lead to stabilization and economic efficiency of their activities.

Keywords: management, vocational qualification development, winemaking industry, personne.

\section{References}

1. Grehem, H. T., \& Bennett, R. (2003). Upravlenie chelovecheskimi resursami (T. Yu. Bazarova \& B. L. Eremina, Ed.). YuNITI-DANA.

2. Kibanov, A. Ya. (2002). Osnovyi upravleniya personalom. INFRA.

3. Savchenko, V. A. (2002). Upravlinnia rozvytkom personalu. KNEU.

4. Maslov, E. (2000). Upravlenie personalom predpriyatiya (P. Shemetov, Ed.). Novosibirsk: INFRA-M.

5. Shekshnya, S. (2014). Upravlenie personalom sovremennoy organizatsii. Biznes-shkola - Intel-Sintez.

6. Adamenko, E. (2015). Professionalnoe obuchenie personala. Menedzher po personalu., (11), 58-62.

7. Mirovoy vinnyiy ryinok: pereraspredelenie sil. (2013). Retrieved from http://ubr.ua/market/ agrIculturalmarket/vInnyI-rynok-otrezvlIaushIe-tendencII-261254

8. Povalyaeva, M. N. (2013). Poryadok obucheniya rabochego personala. Upravlenie razvitiem personala, (01 (09)), 36-45.

9. Karlovets, S. S. (2011). Problema razvitiya personala: sovremennyiy vzglyad. Upravlenie razvitiem personala, (01 (25)), 26-31.

10. Doklad o razvitii cheloveka za 2015 god. Nyu-York, po zakazu PROON. (pp. 1-262, Rep.). (2015). NyuYork.

11. Ctan vynorobnoi haluzi u sviti. Retrieved from http://take-profit.org/ economicnews.php.

Received 8 October 2017

Approved 22 October 2017

Available in Internet 30.12.2017 